\title{
Lesson Study to Improve Students' Self-Directed Learning in Mathematics
}

\author{
Baidowi Baidowi \\ Mathematics Education Study Program \\ Universitas Mataram \\ Mataram, Indonesia \\ Nurul Hikmah \\ Mathematics Education Study Program \\ Universitas Mataram \\ Mataram, Indonesia
}

\author{
Eka Kurniawan \\ Mathematics Education Study Program \\ Universitas Mataram \\ Mataram, Indonesia \\ Ratih Ayu Apsari* \\ Mathematics Education Study Program \\ Universitas Mataram \\ Mataram, Indonesia \\ ra.apsari@unram.ac.id
}

\begin{abstract}
Being independent in learning or usually be called as having self-directed learning ability is important to determine the success of study in higher education. However, based on the observation in the previous academic semester, it was found that the students in mathematics education study program tend to wait their lecturers to inform the knowledge without any effort to learn independently. Therefore, the present study aimed to develop the students' self-directed learning skill through the implementation of lesson study. The steps applied are Plan, Do and See repeated in three cycles. The subject of the study was 20 third year-students of mathematics education study program who took of Capita Selecta in Mathematics course. Data were gathered using observation technique and analyzed qualitatively using descriptive method to gain the relationship between the quality of learning process and students' self-directed learning. The study revealed that lesson study in Capita Selecta in Mathematics was able to enhance students' self-directed learning. It can be seen from the students' awareness to learn the upcoming study materials and contribute in discussion with lecturer and their peers.
\end{abstract}

Keywords - lesson study, self-directed learning, capita selecta in mathematics

\section{INTRODUCTION}

The current intention in education is to support the students to develop their problem solving, communication, inter- and intrapersonal abilities, ethics and esthetic skills [1]. Since the educational goals are complex, the students need to have awareness to initiate their learning process independently. Therefore, the learning experiences will not be limited merely in the classroom meeting. This awareness is called by self-directed learning, a tendency to organize learning without waiting someone to direct [2].

Self-directed learning is developed by the commitment of the person to obey the rules in the community [3]. The ability to manage the rhythm in learning depends on the person's surroundings, including parents and parenting pattern, environment and school. Therefore, even though it is considered as an internal individual skills [4], the realization and the improvement need conditioning support from others.

In the educational field, self-directed learning is necessary to ensure the students' ability to be responsible towards their decision. It also useful to enable the students in transferring their knowledge in to the daily life practices, controlling their learning activity without being exclusive and separated from others, and also developing their critical thinking, curiosity and activity in learning [5].

The previous studies showed that the improvement in students' self-directed learning contributed to the increase on students' learning outcome [6], [7] \& [8]. It is because the students are able to organize their own learning and set a holistic comprehension on the topic as the learning goals [9].

One of the courses in mathematics education department which has yearly problem due to the students' low learning achievement is Capita Selecta in Mathematics. Our preliminary study showed that it was due to the lack of students' self-directed learning. The students were usually waiting for the lecturer to explain the learning materials. Furthermore, they also did not actively participate in the classroom or group discussion and usually late in assignment submission. All of the passive learning patterns assigned to the less ideal learning result.

The condition is harmful for the future of the students since most of the mathematics education study program's students will be the mathematics teacher in the future. As a teacher, one is expected to know how to deal with learning rhythm so they can help their students to develop theirs. Moreover, as one of the basic course, Capita Selecta in Mathematics is acknowledged as a crucial subject to the prospective mathematics teacher.

Reflecting to the aforementioned condition, the mathematics education department felt the urge to do improvement in learning to make the course become more systematic. By doing that, the students are expected to enhance their self-directed learning. To achieve the goal, lesson study was chosen as the method to solve the problem in Capita Selecta in Mathematics. Lesson study is a collaborative teaching activity conducted by several lecturers in order to plan, implement, observe and report the learning process and results. It is conducted to create a sustainable learning community that continuously improve the quality of learning organization [10].

Lesson study is acknowledged as an appropriate solution since it can help the lecturers to gain understanding of how the students learn and how the lecturer teach [11]. Therefore, 
the lecturer's activity can be guided into better results in the future [12]. According to Rock \& Wilson [13], the improvement in learning process after the implementation of lesson study is caused by the input given by the colleagues (who act as lesson study team/observer) and the opportunity to discuss what to improve for the better lesson. Therefore, the difficulties in teaching and learning can be evaluated to find the best solution and it affect the students' learning success.

Besides that, by conducting lesson study, the lecturers and the students can observe the most useful strategy to improve the students' self-directed learning. This is in line with a recommendation to support the prospective teachers to build an effective strategy in building their self-directed learning so they will be able to support their future students in developing their self-directed learning [14]. From the aforementioned problem and condition, this study was aimed to improve the students' self-directed learning by the implementation of lesson study in Capita Selecta in Mathematics course.

\section{METHODS}

This research is a Classroom Action Research (CAR) which is implementing Lesson Study in the teaching and learning process. Lesson Study is a teacher's professional development which is conducted collaboratively and continuity using the learning together principal to develop learning community [15]. By the implementation of lesson study, the educator's skills and competence in conducting a good lesson can be improved [12].

Before implementing lesson study, initial observation was conducted to identify the learning problems in the classroom. After that, we continued to the lesson study phases, which are Plan, Do, See. The phases are repeated in three cycles.

During the Plan stage, the researchers designed the learning instruments, starting from choosing the learning topics, formulating lesson plan, constructing learning materials and observation sheets, and analyzing students' initial ability to make an equal group. In the Do stage, the lesson plan and materials were implemented in the classroom. There are three lecturers participated in the Do Stage, one as Model Lecturer whose responsibility is to conduct the lesson while the other two become the observers. Reflection of overall teaching implementation were carried in the last stage, See. The evaluation result will be the recommendation for the researchers in revising the lesson plan and materials.

The participants of the study were 20 third-year students of mathematics education study program who took Capita Selecta in Mathematics course. The data were collected from classroom observation and self-directed learning questionnaire was given in the end of each cycle. The observation sheet employed in this study consists of the following indicators:

TABLE 1. STUDENTS' SELF DIRECTED LEARNING OBSERVATION SHEET

\begin{tabular}{|l|l|l|l|}
\hline No. & \multicolumn{1}{|c|}{ Activities } & $\begin{array}{c}\text { Number of } \\
\text { Students }\end{array}$ & $\begin{array}{c}\text { Percentage } \\
(\%)\end{array}$ \\
\hline 1. & $\begin{array}{l}\text { Independently learn about the } \\
\text { upcoming topic }\end{array}$ & \\
\hline 2. & Initiate discussion with lecturer & & \\
\hline
\end{tabular}

\begin{tabular}{|l|l|l|l|}
\hline No. & \multicolumn{1}{|c|}{ Activities } & $\begin{array}{c}\text { Number of } \\
\text { Students }\end{array}$ & $\begin{array}{c}\text { Percentage } \\
(\%)\end{array}$ \\
\hline 3. & Answer a question & & \\
\hline 4. & $\begin{array}{l}\text { Actively engage in group } \\
\text { discussion }\end{array}$ & & \\
\hline 5. & $\begin{array}{l}\text { Provide good explanation during } \\
\text { presentation }\end{array}$ & & \\
\hline
\end{tabular}

The data from observation were analyzed qualitatively using descriptive method [16]. Meanwhile, the data from test and questionnaire were analyzed quantitatively using descriptive method. The category used to distinguish students' directed learning ability can be seen in the Table 2 .

TABLE 2. SELF-DIRECTED LEARNING

\begin{tabular}{|c|c|}
\hline Percentage & Category \\
\hline $80 \% \leq p \leq 100 \%$ & Very Good \\
\hline $60 \% \leq p \leq 80 \%$ & Good \\
\hline $40 \% \leq p \leq 60 \%$ & Satisfactory \\
\hline $20 \% \leq p \leq 40 \%$ & Poor \\
\hline $0 \% \leq p \leq 20 \%$ & Very Poor \\
\hline
\end{tabular}

\section{RESULTS AND DISCUSSION}

The study was carried in the Capita Selecta in Mathematics course with Absolute Value, Logarithm and Limit topics in each cycle of I, II, and III. According to lesson study principles where some educators are gathered in the same class to observe the lesson, in this study we assigned one lecturer to conduct the learning flows and the other 2 lecturers as observers.

Before conducting the lesson, after preliminary observation, the researchers formulated the following items during the Plan stage.

1. Lesson Plan.

2. Students' Learning Activity.

3. Lecturer' and Students' Activities Observation Sheets.

4. Students' organization plan during classroom: 4-5 students in each group.

The plans were implemented in Do stage and reflected in See stage. Figure 1 shows the observation result of students' self-directed learning based on the activity indicators provided in Table 1.

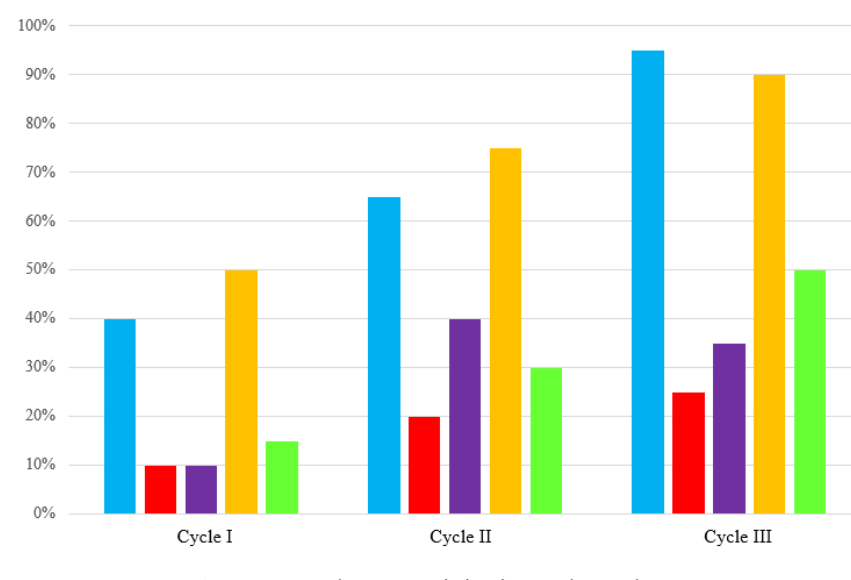

Figure 1. Students' Activity in Each Cycle 
Figure 1 shows how the activities are growing in each cycle. From the observation, it can be seen that the students' activity increased in each cycle. It means that more students were showing their self-directed learning.

There are 55\% improvement in Activity 1, from $40 \%$ in Cycle I to $95 \%$ in Cycle III. It means students' awareness to learn upcoming topic before the lesson were developed. It is happened due to the method used by the lecturers in introducing the upcoming materials for the next class that motivate the students to learn about it.

The improvement also supported by the learning method employed in the classroom through the use of students' worksheet and small group discussion. From the observation, it was found that in the beginning, the students depended on the smartest student in the group to solve the given problem. To minimize the tendency, we added more problems in the students' worksheet which is including homework problems related to the upcoming topic materials. By that intervention, the students were having more chances to try the problems by themselves at home, not merely waiting for their friends to solve it.

The effectiveness of the homework can also be seen in the Activity 3 and Activity 4 in which the students who learn the materials before the class were more active in classroom discussion and in answering the lecturer's questions. The similar result related to the benefits of homework to enhance the students' self-directed learning also can be read in Effeney, Carroll \& Bahr [17]. The possible reason behind the better result on students' self-directed learning is because the students were having a regular homework that made them get used to build a strong foundation to learn outside the regular classroom meeting.

Moreover, the students' ability in posing a problem was also increased, as can be seen in the progress of Activity 2 from Cycle I to Cycle III, although it was not as dramatic as other activities. Based on the observation, the increase in students' problem posing is supported by the feedback given by the lecturer. However the improvement is not optimum yet since the feedback was not effectively triggering the students to ask further questions. This finding is in line with the study of Yang [18] that revealed how the educators struggling to enhance the students' participation in asking question because they were not fully patient in waiting the questions emerged and have difficulty in giving appropriate feedback.

The significant improvement can be seen in Activity 5 which was increased $35 \%$, from $15 \%$ in Cycle I to $50 \%$ in Cycle III. From the observation, this might be due to students' familiarity in small group discussion setting. It influenced the students' awareness in working with their homework that further help them to learn before the classroom meeting. Afterwards, the students realized their role and responsibility to accomplish the group assignment. The consciousness to be responsible with their groups motivated the students to develop a comprehensive understanding during group discussion and contribute in classroom discussion during presentation.

The aforementioned type of awareness is the realization of self-directed learning in which a person be responsible toward his/her own decision in solving a task [19]. Moreover, the willingness to share an idea in a discussion is a potential part to be developed further in order to construct the students' self-directed learning [20].

The improvement of students' self-directed learning is closely associated to the depth observation setting conducted during lesson study. The finding of Geduld [21] highlighted that most of the participants were acknowledged self-directed learning as important factor to determine their success in learning, theoretically and practically. However, more than half of them were not showing any pattern that indicate selfdirected learning. This study gained a better result because the lecturers are actively observe the students' activity in depth and structured. It can be seen in the increase of the students' activities and the better pattern of students' selfdirected learning.

The students' self-directed learning development was growing together with the improvement of lecturer's activities recorded on the observation sheet. The evaluation scale used were: $\mathrm{VG}=$ very good, $\mathrm{G}=\operatorname{good}, \mathrm{S}=$ Satisfactory, $\mathrm{P}=$ poor, $\mathrm{VP}=$ very poor. The summary of the lecturer's activity can be observed in the following table:

TABLE 3. LECTURER'S ACTIVITY OBSERVATION

\begin{tabular}{|c|l|c|c|c|}
\hline \multirow{2}{*}{ No. } & \multicolumn{1}{|c|}{ Indicator } & \multicolumn{3}{|c|}{ Evaluation } \\
\cline { 3 - 5 } & & $\begin{array}{c}\text { Cycle } \\
\text { I }\end{array}$ & $\begin{array}{c}\text { Cycle } \\
\text { II }\end{array}$ & $\begin{array}{c}\text { Cycle } \\
\text { III }\end{array}$ \\
\hline 1. & Lesson preparation & VG & VG & VG \\
\hline 2. & $\begin{array}{l}\text { Apperception and motivation } \\
\text { for the students }\end{array}$ & VG & VG & VG \\
\hline 3. & $\begin{array}{l}\text { Organize students in group } \\
\text { discussion }\end{array}$ & VG & VG & VG \\
\hline 4. & $\begin{array}{l}\text { Facilitate students in } \\
\text { presentation and discussion }\end{array}$ & VG & VG & VG \\
\hline 5. & Give feedback & $\mathrm{G}$ & $\mathrm{G}$ & VG \\
\hline 6. & Learning Reflection & $\mathrm{G}$ & $\mathrm{G}$ & $\mathrm{G}$ \\
\hline
\end{tabular}

From Table 3, it can be inferred that the lecturer's activity was in a very good quality. In addition, the point on "giving feedback to the students" and "learning reflection" need to be improved further. Both indicators are closely affiliated to ensure the quality of communication between the students and lecturer.

As explained previously, compared to other activities, Activity 2 (the students' problem posing indicator) was the least improved activity in the present study (35\% in Cycle III). Therefore, the lecturer is expected to consider the questioning strategy used in the classroom to encourage the students' in posing a problem [22].

The current study also found that even though until the last cycle the students were still consuming longer time to solve a higher level question, the students were actively discuss it with their groups. The students also supported their arguments during discussion with appropriate source of references. The finding is in line with the study of of Ergen \& Kanadli [8] that the students' self-directed learning is an essential support to enable the life-long learning principals since they will not be a passive learner who wait someone to tell them the materials, but actively find knowledge and chance to learn something new.

From Table 3, it can also be observed that the lecturer showed a very good behavior in opening the lesson and 
giving apperception. Those findings are highly important in the present study since, based on the preliminary observation, it was found that the students were having a problem with their pre-requisite knowledge. Hence, the lecturer's role in enchanting the students' memories related to the relevantprevious learning topics are strongly beneficial. By that, the students can be stimulated to use their preliminary understanding as a rich source to discuss the upcoming topic.

Furthermore, the students' self-directed learning was also impacted by the opportunities provided by the lecturers to enable them in using as many references as possible to enrich the group discussion in the related topic. The finding is relevant to the recommendation of Song \& Hill [23] that the students should be given enough spaces to use unlimitedrelated reference during learning. In addition, in order to enhance the students' learning outcome, the lecturer should also provide a meaningful scaffolding [24].

\section{CONCLUSION}

Reflecting on the result of the study, it can be concluded that the students' self-directed learning can be improved by the implementation of lesson study. The improvement can be seen from the observation of students' activity during the lesson, including studying the topic materials before the meeting and participating in the discussion. Therefore, it is recommended to implement lesson study in other courses to enhance the quality.

\section{REFERENCES}

[1] Aunurrahman. Belajar dan Pembelajaran (Learning and Teaching). Bandung: Alfabeta, 2009.

[2] Darajat. Perawatan Jiwa Untuk Anak (Caring Children's Soul). Jakarta: Bulan Bintang, 1983

[3] Asrori, M. Psikologi Pembelajaran (Educational Psychology). Bandung: Wacana Prima, 2007.

[4] Ali, M. \& Asrori, M. Psikologi Remaja-Perkembangan Peserta Didik (Psychology for Adolescent - Students Development. Jakarta: Bumi, 2004.

[5] Siriwongs, P. Developing students' learning ability by dint of self-directed learning. Procedia - Social and Behavioral Sciences, 197, 2074-2079, 2015.

[6] Pedrosa, D., Cravino, J., Morgado, L., \& Barreira, C. Selfregulated learning in higher education: strategies adopted by computer programming students when supported by the SimProgramming approach. Production, 27, 1-15, 2017.

[7] Mutawah, M. A., Thomas, R., \& Khine, M. S. Investigation into self-regulation, engagement in learning mathematics and science and achievement among Bahrain secondary school students. International Electronic Journal of Mathematics Education, 12, 633-653, 2017.

[8] Ergen, B., \& Kanadli, S. The effect of self-regulated learning strategies on academic achievement: A meta- analysis study. Eurasian Journal of Educational Research, 69, 55-74, 2017.

[9] Harding, S., Nibali, N., English, N., Griffin, P., Graham, L., Alom, B.M., Zhang, Z. Self-regulated learning in the classroom: Realising the potential for Australia's high capacity students. Assessment Research Centre, Melbourne Graduate, 2018.

[10] Misnasanti, Dien, C., \& Azizah, F. The roles of lesson study in the development of mathematics learning instrument based on learning trajectory. Journal of Physics, instrument based

[11] Cerbin, W., \& Kopp, B. Lesson study as a model for building pedagogical knowledge and improving teaching. International Journal of Teaching and Learning in Higher International Journal of Teachin
Education, 18, 250-257, 2006.

[12] Rusman. Model Model Pembelajaran (Learning Models). Bandung: Rajawali Press, 2010.

[13] Rock, T. C., \& Wilson, C. Improving teaching through lesson study. Teacher Education Quarterly, 32, 77-92, 2005.

[14] Mirhosseini, F. S., Lavasani, M. G., \& Hejazi, E. The effectiveness of self-regulation learning skills on motivational and academic variables among students. World Family Medicine, 16, 68-75, 2018.

[15] Maths Development Team. A Handbook for Lesson Study: Including a Research Lesson Proposal Template. Ireland: PDST, 2017.

[16] Miles, M., Huberman, A., \& Saldaña, J. Qualitative Data Analysis: A Methods Sourcebook (3rd ed.). Thousand Oaks, California: SAGE Publications, 2014.

[17] Effeney, G., Carroll, A., \& Bahr, N. Self-Regulated Learning: Key strategies and their sources in a sample of adolescent males. Australian Journal of Educational \& Developmental Psychology, 13, 58-74, 2013.

[18] Yang, H. A research on the effective questioning strategies in class. Science Journal of Education, 5, 158-163, 2017.

[19] Baars, M., Wijnia, L., \& Paas, F. The association between motivation, affect, and self-regulated learning when solving problems. Frontiers in Psychology, 8, 1-12, 2017.

[20] Thornton, K. Supporting self-directed learning: A framework for teachers. Language Education in Asia, 1, 158-170, 2010.

[21] Geduld, B. Teachers' perceptions of how they develop selfregulated learning. Perspectives in Education, 35, 143-156, 2017.

[22] McCarthy, P., Alec, S., McCarthy, P., Cho, J.-p., \& Gyan, E. Teacher questioning strategies in mathematical classroom discourse: A case study of two grade eight teachers in Tennessee, USA. Journal of Education and Practice, 7, 80-89, 2016.

[23] Song, L., \& Hill, J. R. A conceptual model for understanding self-directed learning in online environments. Journal of Interactive Online Learnin, 6, 2842, 2007.

[24] Gita, I.N., \& Apsari, R.A. Scaffolding in problem based learning to increase students' achievements in linear algebra. Journal of Physics, 1040, 1-7, 2018. 